ECONOMICS

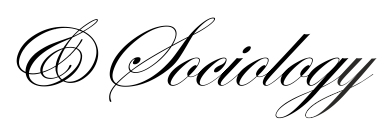

\title{
INTERNATIONAL SHARING ECONOMY: THE CASE OF AIRBNB IN THE CZECH REPUBLIC
}

\author{
Aleksandr Ključnikov, \\ Pan-European University, \\ Bratislava, Slovakia, \\ E-mail:kliuchnikov@gmail.com \\ Vladimír Krajčík, \\ University of Business and Law, \\ Prague, Czech Republic, \\ E-mail:kliuchnikov@gmail.com \\ Zuzana Vincúrová, \\ Pan-European University, \\ Bratislava, Slovakia, \\ E-mail: \\ zuzana.vincurova@paneurouni.com
}

Received: February, 2018

1st Revision: March, 2018

Accepted: May, 2018

DOI: $10.14254 / 2071-$

789X.2018/11-2/9

\begin{abstract}
The concept of the sharing economy in accommodation business, an explosively growing business model, influences housing and hotel markets worldwide. The aim of this paper is to investigate the size of the AirBnB sector in Prague, to identify a potential disruption of the accommodation market and the potential scale of tax evasion of the AirBnB users, to state the need for additional regulation in this field. The research data were collected using the method of webscrapping from AirBnb website, then validated using the AirDNA database (18 586 units, 1048585 records, April 2016 to March 2017). The tax evasion was measured through authors' own model. The main results are as follows: through the offer of accommodation via AirBnB platform in Prague is extensive and compatible with the capacity of Prague hotels; the average occupancy rate in Prague is highly above the values of 14 largest European cities; $80 \%$ of the real estate units offered through the AirBnB platform do not represent the case of the usual sharing economy, but are a subject to taxes. The data on Prague substantially outstrips the European average, thus indicating to a potentially significant misuse of the AirBnB platform and a low-scale associated potential tax evasion. Czech legislation is well prepared for sharing economy. $7.4 \%$ of the AirBnB users control $39.56 \%$ of all accommodation options offered via this platform in Prague.
\end{abstract}

JEL Classification: F23, H24, Keywords: sharing economy; airBnB; taxation; market share; H25, L26, K20, M21 Prague

\section{Introduction}

Sharing economy is a sustainable economic system, where the key element is the sharing of private assets by individuals. The concept of sharing economy in accommodation business brings benefits to both customers and local municipalities, but at the same time it might threaten the quality of life of local citizens, impose negative influences on the local housing and hotel markets, as it is widely discussed in (Rodas Vera \& Gosling, 2017; Barata-Salgueiro, 2017; Horn, Merante, 2017; Gurran, Phibbs, 2017; Yrigoy, 2017; Wegmann \& Jiao, 2017 etc.). Most of these and other authors agree that sharing economy concept has a disruptive influence on the 
local accommodation business performance, and that local authorities should evaluate its impact and discuss the possibilities of state regulation for this new type of peer-to-peer economy in order to protect business environment in local communities (Barata-Salgueiro, 2017; Gurran, Phibbs, 2017; Yrigoy, 2017; Wegmann \& Jiao, 2017; Kovács \& Kot, 2017; Streimikiene \& Bilan, 2015). On the other hand, Horn \& Merante (2017) claim that currently there is limited evidence on whether home sharing affects the housing market, while policy makers grappling with the effects of rapid growth of home sharing have inadequate and insufficient information to make well grounded policy decisions.

While regulation of entrepreneurship in the segment of sharing economy is currently a widely discussed issue, the ways of its regulation differ. In the cities, where the regulation has been already applied, the main approaches vary from total prohibition of short-time rental via AirBnB to imposing limitation on the number of days the property may be offered for rent during a year, with the most frequent limits from 60 to 180 days per year. The limit of 60 rental nights per calendar year is set in Amsterdam and San Francisco. 90-day limit is currently used in Berlin (starting on 1.5.2018), London, Reykjavik, New Orleans and Philadelphia. Paris limits short-term rentals by 120 nights per calendar year, Portland has 30-day limit, and Toronto 28 days only. Relatively moderate regulation is being used in Los Angeles and Miami with a 180-day per year limit. No specific regulation has been implemented in Chicago, Seattle, Boston and San Diego. Short-term rental is prohibited as such in Las Vegas, Orlando, Washington DC (for the cases when owners do not reside in the same house) and New York (in buildings with three or more units, renting out for less than 30 days is illegal). Other specific regulations are applied in Austin, Barcelona and Louisville.

The aim of this paper is to investigate the actual size of the AirBnB accommodation sector in Prague, to identify its specific features and evaluate the situation and the impact of short-term rentals via AirBnB on Prague accommodation market in comparison with other European cities. The partial aim of the paper is to identify a potential disruption of the accommodation market and the potential scale of tax evasion by AirBnB users, so that to explain the need for additional regulation of this segment in Prague.

\section{Literature review}

The database of the Web of Science currently includes 195 articles, at least partially related to AitrBnB platform and its impact on the economy and business. Most of the relevant papers, devoted to this field of study, are very current, published mostly in 2017.

Yrigoy (2017) in his study of the phenomenon of tourism in Minorca found that Airbnb irruption has created the mechanisms to trigger gentrification in the short-run in the Minorca urban settlements, and in fact forces relocation of established residents from a gentrified area to other less touristic interesting locations.

Negative impact of the abrupt growth of AirBnB listings concerning the transformation of private dwellings into tourist dwellings and the effects on the housing market in general on the liveability and security in neighbourhoods and also in condominiums was confirmed by Lambea Llop (2017) in Barcelona.

Wegmann \& Jiao (2017) confirm that urban vacation rentals, a phenomenon that has grown explosively very recently, bring benefits to cities but also impose quality of life and housing market impacts on neighborhoods. The authors conclude that local authorities are beginning to grapple with creating regulatory regimes for sharing economy services, and argue that meaningful regulation necessitates dedicated enforcement, likely paid for with permit fees; and that it is desirable to distinguish between "mom-and-pop" hosts and those operating at a commercial scale. 
Gurran \& Phibbs (2017) in case of Sydney, the largest region in Australia with 4.4 million people in 28 individual municipalities, which has experienced both rapidly rising housing costs and exponential growth in Airbnb listings since 2011, found that online homesharing platforms for visitor accommodations blur traditional boundaries between residential and tourist areas so Airbnb listings may fall outside of existing land use regulations or evade detection until neighbors complain, and in the conclusion of their study they call for regulation of homesharing platforms aiming to regulate potential impacts on neighborhoods and housing markets. The authors also point out the need to distinguish between different forms of short-term Airbnb accommodation listings, because the impact of different types of listings differs.

Horn \& Merante (2017) investigated how the sharing economy is shaping the housing market by focusing on the short-term effects of the growth of Airbnb in Boston neighborhoods on the rental market and examined whether the increasing presence of Airbnb raises asking rents and whether the change in rents may be driven by a decline in the supply of housing offered for rent. Their results showed that a one standard deviation increase in Airbnb listings is associated with an increase in asking rents of $0.4 \%$, which is not a negligible impact, but not a catastrophe.

Xie \& Kwok (2017) in their study of the impact on AirBnB on the performance of nearby hotels in case of Texas also found, that the impact of AirBnB listings was not significant in a long term run. Zervas et al. (2017) in their study of the same region as the previous authors found that AirBnB has the causal impact on hotel revenue is in the 8\%-10\% range especially in case of lowerpriced hotels and hotels that do not cater to business travelers. The most substantial impact manifests itself primarily through less aggressive hotel room pricing especially pronounced during periods of peak demand, which is beneficial for the consumers, not just participants in the sharing economy. The scale of the impact of the performance of the hotel industry in general is not substantial. Several authors also mention (e.g. Kvitkova, 2016) that the hoteliers consider Airbnb as a threat to their business.

The opposite results of the impact of AirBnB on hotel revenues were found by Aznar et al. (2017) in their study from Barcelona. They found a positive correlation between presence of Airbnb apartments and return on equity of the hotels. This fact can be explained by considering the presence of Airbnb apartments as a variable that measures the attractiveness of the location from a tourist's point of view.

Biber et al. (2017) call for a more vigilant approach in case of regulations of the platform (sharing) economy, by claiming that when business innovation upends a pre-existing business model in a regulated industry, the result can be a disjunction between the structure of the regulatory system governing incumbent firms and the firms disrupting the industry. Unnecessary regulation may dismiss the positive effect of new business models that solve problems legal regimes have been designed to address. Moderate approach to regulation is also recommended by Svecova \& Veber (2017). Miguel Rodriguez-Anton et al. (2016) even taking into consideration the fact the European Union has clearly adopted a position in favour of collaborative economy state that in order to have a proper coexistence between the activities developed in a collaborative economy area as well as a traditional one, it is necessary to have regulations providing clear rules of the game.

Tax issues are a partial problem of platform economy regulation. Zu \& Bai (2017) in their study from China point out such problems such as unfair competition with traditional economy and tax evasion and analyze the necessity and feasibility of tax sharing economy business model and recommend strengthening economic supervision and management advice, in order to promote the healthy and orderly development of the sharing economy. 
Some authors have identified that AirBnB platform is used by several large reality market players with the aim to avoid tax and business regulations. For instance, Barr \& Choi (2017) pointed out that some types of listings are receiving the most rentals. Coyle \& YuCheong Yeung (2016) included the number of listings simultaneously offered by particular AirBnB users in their study of AirBnB data from European cities. They found, that in some cases (e.g. Paris, Manchester) the share of owners offering the accommodation in more than five units simultaneously become significant and reaches $2-5 \%$ of all users.

Literature review shows that AirBnB has a certain disruptive influence on the accommodation markets worldwide, that the sharing economy in accommodation business is shaping the housing and accommodation market by focusing the properties on the short-term rentals of the growth of Airbnb, but the results of that influence are different. Further research of the potential need of regulation of this service is obviously desirable.

\section{Methodological approach}

Our research team has focused on two main research problems. The first research topic was aimed on the evaluation of the size of the AirBnB accommodation sector in Prague, identification of its specific features in comparison with the situation in the other European cities. The second research topic was focused at the potential scale of tax evasion of the AirBnB and an identification of the need of regulation of this segment in Prague.

The research problems were divided into four main scientific hypotheses, that were set at the base of the literature review and the method of expert estimation. First two hypotheses are focused on the first research problem, and the last two on the second one. The hypotheses are as follows:

H1. The offer of accommodation via AirBnB platform in Prague is extensive, and compatible with the capacity of Prague hotels.

$\mathrm{H} 2$. The number of listings simultaneously offered by particular AirBnB users is at the average level in the comparison with the other EU cities, and therefore the accommodation market at the AirBnB platform is not highly concentrated.

H3. The scale of potential tax evasion of the AirBnB users is lower than 500 million of the Czech Crowns.

H4. The tax legislation and regulation of the accommodation via AirBnb is sufficient, and does not need substantial changes.

To evaluate the scale of AirBnB influence of the Czech accommodation market we have used a modern method of webscrapping of the data from AirBnb website. This method is widely used, and for instance Wegmann \& Jiao (2017) recommend this method as an effective mean of gathering locally specific data as a background for regulation. Barr \& Choi (2017) used this method in their study of AirBnB regulation in South Korea. The similar approach was also used by Gutiérrez et al. (2017) in their study of the impact of AirBnB in Barcelona. Our IT team has developed a webscrapping tool, that was monitoring the AirBnB website for a couple of months. These own results were collected in order to verify the validity of the data, provided by the AirDNA, mapping the use of the AirBnB platform for a period from 1.4.2016 to 31.3.2017. The data were analyzed with the advanced instruments of Microsoft Excel 2016 software. The data set included the data of the rentals of 18586 properties with the total number of 1048585 records.

For the purpose of modeling of the tax evasion, the research team made an assumption that the most appropriate legal form of provision of accommodation services on the AirBNB platform will be a self-employed entrepreneur without the legal status of a legal entity. In this case the provision of the accommodation services becomes a subject of the following taxes: 
income tax on natural persons, value added tax, social insurance premiums, health insurance premiums, local charges from accommodation capacities.

Revenues from accommodation services falls under article 7 (Revenue from selfemployment) Art. 7 of the Act No.: 586/1992 Coll., on Income Taxes in wording of later amendments (Income Tax Act, ITA) defines the possibility the possibility of application of the flat-rate if the taxpayer does not use the expenditures demonstrably spent on achieving, securing and maintaining income in the amount of $60 \%$ of the income from the entrepreneurial activity, but the maximum amount can be used up to CZK 1,200,000. The basis of the tax is the amount by which the revenue accruing to the taxpayer during a taxable period exceeds the expenses that are demonstrably spent on their achievement, retention and retention. The rate of tax is set at $15 \%$ of the tax base, rounded down to a whole dollar. Income exceeding 40 times the average wage $(2016$ - CZK 1,296,288) is additionally taxed by the so-called solidarity tax under Section $16 \mathrm{a}$ of the ITA at a rate of $7 \%$. For the purposes of our model, we will apply a basic tax deduction to the taxpayer under Section 35ba (1) a) ITA of CZK 24840.

Section 6 (1) of Act No. 235/2004 Coll. on Value Added Tax (hereinafter referred to as the VAT Act) determines that the tax payer becomes a VAT payer automatically in case that the turnover within 12 consecutive calendar months exceeds 1 million CZK. According to $\S 47$ of the VAT Act in the case of accommodation services, 15\% VAT is applied.

According to Act No. 155/1995 On pension insurance the premium rate for selfemployed entrepreneurs currently stands at $29.2 \%$ ( $28 \%$ for pension insurance, $1.2 \%$ for state employment policy) of the assessment base. The resulting premiums are rounded up to the crowns. The basis of assessment for the payment of social security premiums of the selfemployed person is $50 \%$ of the income from business activities and other self-employment after deduction of expenses incurred for its achievement and retention. The maximum basis of assessment for 2016 for social insurance is CZK 1,296,288.

The rate of health insurance is $13.5 \%$ of the assessment base, which is the same as for social insurance. The maximum measurement base is currently not defined. The resulting premiums are rounded up to the crowns.

The collection of the local fees is regulated by Act No. 565/1990 On Local Fees, and generally binding Decree No. 27/2003 Of Prague. The fee administration is governed by Act No. 280/2009 Coll., The Tax Code, as amended. The fee rate for Prague is 15, - CZK per person and for each commenced day of stay.

The final financial model of potential tax evasion, simulated in Microsoft Excel software, included all the mentioned taxes.

\section{Conducting research and results}

Based on AirDNA data we can state that during the period from 1.4.2016 to 31.3.2017 8943 users offered 18548 accommodation via the AirBnB platform in Prague. 75.04\% (13918 units) of the offered units were used at least once during the reporting period. The number of daily offered (active) accommodation units averages between 8 and 12 thousand. Taking into consideration the lowest potential level of the capacity of one accommodation unit of 2 person the total daily capacity of the accommodation offered at the AirBnB platform in Prague reaches the minimum level of 16000 to 24000 beds.

According to the data of the Czech Statistical Office the total number of rooms, offered by the collective accommodation facilities in 2016 was 42081 with 91887 beds.

At the base of the results of the research the hypothesis H1 was confirmed. The offer of accommodation via AirBnB platform in Prague is extensive, and compatible with the capacity of Prague hotels. 
The average occupancy rate, calculated as the ratio of the bookings to the total number of days when the property is available for lease in the reference period in Prague, reached $50.21 \%$, well above the average of 14 European cities, according to Coyle and Yu-Cheong Yeung (2016). 31.69\% on units were occupied for less than 10 percent, $64.75 \%$ were occupied less than 50 percent, and only 5.26\% of the units were occupied for more than 90 percent.

The average occupancy rate in Prague is highly above the values of 14 largest European cities, mentioned in the report of Coyle and Yu-Cheong Yeung (2016), and is even higher than in Amsterdam (39.42\%), that indicates that Prague accommodation market is quite lucrative for AirBnB platform.

Total annual revenues of all units offered through AirBNB in Prague exceed 87 million of USD. More detailed data on average earnings is given in the following table (unified CZK/USD exchange rate of 24.53 published by Czech Ministry of finance for the year 2016 was applied):

Table 1. Yearly income from accommodation offered through AirBNB in Prague (April 2016 to March 2017)

\begin{tabular}{lr}
\hline Total annual yield of all units USD & $\$ 86348464$ \\
\hline Total annual yield of all units CZK & $2118127822 \mathrm{Kč}$ \\
\hline Average annual yield in USD (for units leased for at least 1 day) & $\$ 6204$ \\
\hline Average annual yield in USD (all units) & $\$ 4655$ \\
\hline The \% of units with an average yield lower than 1000 USD & $45,17 \%$ \\
\hline The \% of units with an average yield lower than 10 000 USD & $84,10 \%$ \\
\hline The \% of units with an average yield lower than 30 000 USD & $1,71 \%$ \\
\hline
\end{tabular}

Source: own compilation.

The average annual yield per unit is in the middle of the average values of other European cities according to Coyle and Yu-Cheong Yeung (2016). However, the distribution of rental income is not uniform. The percentage of the units with the average yield lower than $\$ 1000$ per month (45.17\% of all units offered) is above the values of 14 largest European cities.

For the purpose of basic orientation in the scope of potential tax evasion in connection with Czech legislation, we have compiled an overview of the share of total annual and average annual earnings of units rented within 20 days and over 30, 60, 90 and 180 days per year.

Table 2. Total and average revenues according to occupancy rate of accommodation units (April 2016 to March 2017)

\begin{tabular}{lccc}
\hline Number of reservations per year & Share of units & Total revenue & Average revenue per unit \\
\hline 20 day or less & $46,25 \%$ & $\$ 2803547$ & $\$ 327$ \\
\hline More than 20 days & $53,75 \%$ & $\$ 83544917$ & $\$ 8380$ \\
\hline More than 30 days & $47,95 \%$ & $\$ 81533705$ & $\$ 9167$ \\
\hline More than 60 days & $35,39 \%$ & $\$ 74003320$ & $\$ 11272$ \\
\hline More than 90 days & $27,05 \%$ & $\$ 65688611$ & $\$ 13093$ \\
\hline More than 180 days & $12,54 \%$ & $\$ 40308528$ & $\$ 17337$ \\
\hline
\end{tabular}

Note: Total revenue shows the total annual revenue of all accommodation units with the specified number of reservations per year.

Source: own compilation.

These results point to the fact that $80 \%$ of the real estate units offered through the AirBnB platform do not represent the case of the usual sharing economy, the situation when a 
citizen shares his asset with others to a lower extent, but the normal entrepreneurial activity, which is a subject of taxes. Our data confirm that the total number of 18548 accommodation units, offered at the AirBnB platform in Prague, belongs only to 8,943 users of AirBNB, making an average of 2.07 units per user. The offer of a larger number of real estates automatically puts these users in the category of entrepreneurs because this type of activity is defined as a systematic entrepreneurial activity ( $\$ 2$ of Act No. 455/1991 On Trade Licensing). The table below shows the number of users who are currently offering more accommodation units.

The number of users offering a larger number of units, their shares in the total number of units offered through the monitored platform, and the proportion of these units by category is shown in the table below.

Table 3. Number of the AirBnB users and the number of offered units (April 2016 to March 2017)

\begin{tabular}{lccccc}
\hline Number of Units Offered & 1 & 2 & 3 & 4 & 5 and more \\
\hline Number of users in the category & 6316 & 1247 & 472 & 246 & 662 \\
\hline Share of users & $70,63 \%$ & $13,94 \%$ & $5,28 \%$ & $2,75 \%$ & $7,40 \%$ \\
\hline Number of units in the category & 6316 & 2494 & 1416 & 984 & 7338 \\
\hline Percentage of units in the category & $34,05 \%$ & $13,45 \%$ & $7,63 \%$ & $5,31 \%$ & $39,56 \%$ \\
\hline
\end{tabular}

Source: own compilation.

The data from Prague substantially outstrips the European average and indicate a potentially significant misuse of the AirBnB platform for doing business and the associated potential tax evasion. While only $1.56 \%$ of users in $14 \mathrm{EU}$ cities simultaneously offer 5 or more accommodation units (Coyle and Yu-Cheong Yeung, 2016) more that 7.4\% of the users in Prague rent the same number of units. The similar level of market concentration can be found only in Barcelona, with a total of 5,3\% of the users. European comparison of the number of AirBnB listings per user is presented in Table 4.

Table 4. European comparison of the number of AirBnB listings per user

\begin{tabular}{lccccc}
\hline City & 1 listing & 2 Listings & 3 Listings & 4 Listings & 5 or more listings \\
\hline Paris & $90,97 \%$ & $6,73 \%$ & $1,16 \%$ & $0,36 \%$ & $0,77 \%$ \\
\hline Nantes & $89,03 \%$ & $8,61 \%$ & $1,60 \%$ & $0,35 \%$ & $0,42 \%$ \\
\hline Cologne & $88,55 \%$ & $8,33 \%$ & $1,46 \%$ & $0,66 \%$ & $0,99 \%$ \\
\hline Amsterdam & $88,53 \%$ & $7,92 \%$ & $1,85 \%$ & $0,69 \%$ & $1,01 \%$ \\
\hline Strasbourg & $88,53 \%$ & $9,01 \%$ & $1,27 \%$ & $0,47 \%$ & $0,72 \%$ \\
\hline Toulouse & $87,55 \%$ & $9,30 \%$ & $1,53 \%$ & $0,37 \%$ & $1,15 \%$ \\
\hline Munich & $87,30 \%$ & $9,47 \%$ & $1,81 \%$ & $0,79 \%$ & $0,63 \%$ \\
\hline Berlin & $86,18 \%$ & $9,73 \%$ & $2,19 \%$ & $0,72 \%$ & $1,07 \%$ \\
\hline Frankfurt & $86,18 \%$ & $10,34 \%$ & $1,88 \%$ & $0,86 \%$ & $0,74 \%$ \\
\hline Glasgow & $83,50 \%$ & $11,97 \%$ & $2,45 \%$ & $1,09 \%$ & $1,00 \%$ \\
\hline London & $80,89 \%$ & $12,03 \%$ & $3,12 \%$ & $1,27 \%$ & $2,69 \%$ \\
\hline Manchester & $\mathbf{7 8 , 6 1 \%}$ & $13,18 \%$ & $3,72 \%$ & $1,62 \%$ & $2,87 \%$ \\
\hline Edinburg & $\mathbf{7 7 , 8 8 \%}$ & $14,03 \%$ & $4,11 \%$ & $1,66 \%$ & $2,31 \%$ \\
\hline Prague & $\mathbf{7 0 , 6 3 \%}$ & $\mathbf{1 3 , 9 4 \%}$ & $\mathbf{5 , 2 8 \%}$ & $\mathbf{2 , 7 5 \%}$ & $\mathbf{7 , 4 0 \%}$ \\
\hline Barcelona & $\mathbf{6 9 , 3 7 \%}$ & $\mathbf{1 6 , 5 7 \%}$ & $\mathbf{6 , 1 1 \%}$ & $2,65 \%$ & $5,30 \%$ \\
\hline
\end{tabular}

Source: Coyle and Yu-Cheong Yeung, 2016 and own processing and own compilation. 
The date presented in Table 3 points to the alarming concentration of the accommodation market in the hands of a small number of players. 662 players ( $7.4 \%$ of users) control $39.56 \%$ of the market, offering accommodation in 7338 units. A deeper analysis revealed that 15 AirBNB users currently offer more than 50 accommodation units each. The largest number of units is offered by the user \#5282, that offers 116 accommodation units in Prague and has an annual turnover of USD 265,715, followed by the user \#227945 with 93 accommodation units and an annual turnover of 1.660.445 USD.

At the base of the presented results the hypothesis $\mathrm{H} 2$ was rejected. The number of listings simultaneously offered by particular AirBnB users is above the average level in the comparison with the other EU cities. Due to the fact that only $7.4 \%$ of users control $39.56 \%$ of the market we state that the accommodation market at the AirBnB platform is highly concentrated.

The second part of the research was devoted to the potential tax evasion of the AirBnB users.

The primary conditions for the separation of the activities of the entities from the segment of the sharing economy and the activities of the entrepreneurial subject are currently determined by Czech Act No. 455/1991 On Trade Licensing, which defines the entrepreneurship as a continuous business activity operated independently, on the own behalf of the entrepreneur, on its own responsibility for profit. Taking into account the nature of the sharing economy, we must further distinguish the so-called community sharing, which does not lead to any significant economic effect or specific financial profit.

In the case of the condition of the continuity we have defined the annual limit of the offer of the accommodation unit at the level of 20 days, that represents the length of the average annual holiday time for the usual Czech households. This length of rent to our expert opinion represents the classic case of a community sharing.

The condition of a significant economic effect is defined in the spirit of $\S 10 \mathrm{a}$ of ITA, defining the tax exemption of income from occasional activities up to CZK 30.000 for the taxable period in the scope of $\S 10$ Section 3a of ITA. Even though according to the ITA the exception does not apply to a short-term rent, due to the fact that the annual turnover of entities fulfilling this condition amounts to only USD 1,019,023, which is only $1.18 \%$ of the total turnover offers of accommodation services on the AirBnB platform in Prague, that includes 47 percent of all AirBnB providers (4233 total), only 2028 of which rented the unit for at least 1 day per year during the monitored period and reached an annual average turnover of USD 502.47 (CZK 12,325.59) we consider this set the threshold as economically and socially fair.

In the next step we have created a model of a potential tax evasion of the AirBnB segment in Prague. The model has following all known tax, social insurance, medical insurance, pension insurance, local tax and other legislation of the Czech Republic. We divided the tax payers into several groups with the different set up of conditions, tax types and rates, and taxable incomes. For instance, VAT was applied only at the entrepreneurs with the annual turnover over 1 mil. CZK. So-called solidarity tax was applied in case of the income above 1.490.731,2 CZK. All known income ceilings, tax recognizable expenditures ceilings, insurance premium calculation ceilings were included in the model. The results of the modelling are presented in the following table. 
Table 5. European comparison of the number of AirBnB listings per user

\begin{tabular}{lcc}
\hline Tax or insurance premium & Amount in CZK & Share of the turnover \\
\hline Income tax & 119628533 & $5,69 \%$ \\
\hline Including solidarity tax & 23317778 & $1,11 \%$ \\
\hline VAT & 158570526 & $7,54 \%$ \\
\hline Social insurance premium & 114791229 & $5,46 \%$ \\
\hline Medical insurance premium & 68634123 & $3,26 \%$ \\
\hline Total & $\mathbf{4 6 1 6 2 4 ~ 4 1 1}$ & $\mathbf{2 1 , 9 4 \%}$ \\
\hline
\end{tabular}

Source: own compilation.

Taking into consideration that the chosen method of data collection does not allow the number of persons accommodated within a single reservation to be determined, the extent of the potential amount of the local charge on the accommodation capacity can only be estimated. Taking into account the total number of 1,112,702 bookings per year and the estimated average number of 1.5 to 2 persons per reservation, Prague should collect at least an amount between 27,263,295 CZK to $36,351,060 \mathrm{CZK}$ for the period of 12 months.

The modeling results indicate the maximum potential range of tax evasion in the sector of accommodation services offered through AirBNB. In fact, tax evasion is likely to be significantly smaller, as it can be assumed that the provider of accommodation, which currently operates a larger number of accommodation units, is currently registered as a tax payer. The model implemented in MS Excel allows to selectively calculate the potential tax loss for providers with a defined number of units offered. A strong concentration of supply (see Table 3), with only $7,40 \%$ of users offering 5 or more units simultaneously controlling $39,56 \%$ of the market, suggests the presence of a number of large business entities using sharedeconomy platforms as a business model.

According to the results of our model the hypothesis $\mathrm{H} 3$ was confirmed. The scale of potential tax evasion of the AirBnB users is lower than 500 million of the Czech Crowns.

The analysis of the related legislation, included in the model implies, that the current state of Czech tax, licensing and insurance legislation is well prepared for this specific business segment, and does not need substantial changes. Hypothesis H4 was confirmed.

\section{Discussion}

Our finding that almost 47 percent of all AirBnB providers in Prague reached an annual average turnover of only USD 502.47 (CZK 12,325.59) and the conclusion, that this segment does not need additional regulation of the Czech authorities is conformal with the statement of Gurran \& Phibbs (2017), who pointed out the need to distinguish between different forms of short-term Airbnb accommodation listings, because the impact of different types of listings differs. In our opinion the authorities in case that they will decide to implement regulatory measures should focus their attention on the AirBnB providers exploit their real estate units for more than 30 days a year.

Our finding that additional regulation of a segment of a real community sharing, which to our expert opinion in the conditions of the Czech Republic includes rentals for a period up to 20 days during one year, is not desirable, confirms the finding presented by Biber et al. (2017), who stated that unnecessary regulation may dismiss the positive effect of new business models that solve problems legal regimes have been designed to address, and who call for a more vigilant approach in case of regulations of the platform (sharing) economy, and the 
recommendation of Svecova \& Veber (2017), who recommended to apply a moderate approach to regulation in this field. The approach to regulation of AirBnB rentals in the form of the limitation of the number of days the property may be offered for rent during the year at the level of 60 days in Amsterdam and 90 in London, and a continuous discussion in the mass media about lowering this limit to 30 days per year confirm, that this research statement has a solid number of supporters in the academic environment.

On the other side our finding, that Prague accommodation market via AirBnB platform shows the signs of significant concentration, when only $7,40 \%$ of users control $39,56 \%$ of the market are conformal with the conclusions of Miguel Rodriguez-Anton et al. (2016), that it is necessary to have regulations providing clear rules of the game.

This alarming finding is conformal with the results of Barr \& Choi (2017), who pointed out the concentration of supply in hands of some users, and Coyle \& Yu-Cheong Yeung (2016), who found the similar situation in Barcelona, London, Manchester and Edinburg.

In relation to our finding that a number of large business entities uses shared-economy platforms as a business model we can agree with Zu \& Bai (2017) and state that strengthening of economic supervision of the largest AirBnB providers in Prague by the state authorities may promote the healthier development of the sharing economy in this region.

\section{Conclusion}

The aim of the paper is to investigate the size of the AirBnB accommodation sector in Prague, identify its specific features, compare them with the situation in the other European cities. The partial aim of the paper is to identify a potential disruption of the accommodation marker and the potential scale of tax evasion of the AirBnB users, and to state the need of additional regulation of this segment in Prague.

The main results of the research are as follows. The offer of accommodation via AirBnB platform in Prague is extensive, and compatible with the capacity of Prague hotels. The average occupancy rate in Prague is highly above the values of 14 largest European cities, and is even higher than in Amsterdam (39.42\%), that indicates that Prague accommodation market is quite lucrative for AirBnB platform. Our findings in relation to the earnings of the accommodation providers via $\mathrm{AirBnB}$ platform demonstrate that $80 \%$ of the real estate units offered through the AirBnB platform do not represent the case of the usual sharing economy, but the normal entrepreneurial activity, which is a subject of taxes. The data from Prague substantially outstrips the European average and indicate a potentially significant misuse of the AirBnB platform for doing business and the associated potential tax evasion. On the other side the scale of the potential tax evasion according to our quantitative model is not extreme, and is lower than 500 million of the Czech Crowns. The analysis of the related legislation, included in the model implies, that the current state of Czech tax, licensing and insurance legislation is well prepared for this specific business segment, and does not need substantial changes.

The number of listings simultaneously offered by particular AirBnB users is above the average level in the comparison with the other EU cities. Due to the fact that only $7.4 \%$ of users control $39.56 \%$ of the market we also conclude that the accommodation market at the AirBnB platform is highly concentrated. Deeper analysis revealed that 15 AirBNB users currently offer more than 50 accommodation units each.

We consider the scale and validity of our dataset, covering the real business activities of all AirBnB users in Prague during the 12 months period, that was also validated by our own data scrapping application, for a strength of our research. The greatest potential deviation from the reality may occur in our tax evasion model due to its initial assumptions, but in our view 
the real extent of tax evasion is even lower. We would like to validate the results of our research in case of other large cities in the V4 countries in the future.

\section{Acknowledgement}

The authors are thankful to the NFPP and project VEGA 2/0026/15 for financial support to carry out this research.

\section{References}

Act No.: 586/1992 Coll. Of the Czech Republic, on Income Taxes in wording of later amendments (Income Tax Act).

Aznar, J. P., Sayeras, J. M., Rocafort, A., \& Galiana, J. (2017). The irruption of Airbnb and its effects on hotel profitability: An analysis of Barcelona's hotel sector. Intangible Capital, 13(1).

Barata-Salgueiro, T. (2017). Short rentals in Lisbon. Scripta Nova-Revista Electronica De Geografia Y Ciencias Sociales, 21(578), 1-43.

Barr, J., Choi, B. (2017) Current Trends and Regulatory Impact on Home Sharing Businesses in Seoul, South Korea. Journal of Tourism and Leisure Research, 29(9), 425-441.

Biber, E., Light, S. E., Ruhl, J. B., \& Salzman, J. (2017). Regulating Business Innovation as Policy Disruption: From the Model T to Airbnb. Vanderbilt Law Review, 70, 1561.

Coyle, D., Yu-Cheong Yeung, T. (2016). Understanding AirBnB in Fourteen European cities. The Jean-Jacques Laffont DIGITAL CHAIR - Working Papers.

Gutiérrez, J., García-Palomares, J. C., Romanillos, G., \& Salas-Olmedo, M. H. (2017). The eruption of Airbnb in tourist cities: Comparing spatial patterns of hotels and peer-to-peer accommodation in Barcelona. Tourism Management, 62, 278-291.

Gurran, N., \& Phibbs, P. (2017). When tourists move in: how should urban planners respond to Airbnb? Journal of the American planning association, 83(1), 80-92.

Horn, K., \& Merante, M. (2017). Is home sharing driving up rents? Evidence from Airbnb in Boston. Journal of Housing Economics, 38, 14-24.

Kvitkova, Z. (2016). Analysis Of Airbnb Accomadation Offer In Prague And Comparison Of Selected Indicators With Collective Accomodation Establishments. In: 8th International Annual Scientific Conference on Hotel Services, Tourism and Education, Prague, Czech Republic, 10-19, pp. 83-92.

Kovács, G., \& Kot, S. (2017). Economic and social effects of novel supply chain concepts and virtual enterprises. Journal of International Studies, 10(1), 237-254.

Lambea Llop, N. (2017). A policy approach to the impact of tourist dwellings in condominiums and neighbourhoods in Barcelona. Urban Research \& Practice, 10(1), 120-129.

Miguel Rodriguez-Anton, J., del Mar Alonso-Almeida, M., Rubio-Andrada, L., \& Celemin Pedroche, M. S. (2016). Collaborative economy. An approach to sharing tourism in Spain. Ciriec-Espana Revista De Economia Publica Social Y Cooperativa, 88, 259-283.

Rodas Vera, L. A., \& Gosling, M. D. S. (2017). Sharing Economy In Tourism: A Theoretical Discussion About Collaborative Consumption And Sharing. Revista Eletronica De Estrategia E Negocios-Reen, 10(1), 226-251.

Streimikiene, D., \& Bilan, Y. (2015). Review of rural tourism development theories. Transformations in Business \& Economics, 14(2), 21-34. 
Svecova, L., Veber, J. (2017). Is The Sharing Economy Unfair Competition And Should It Be Regulated? In: IDIMT-2017 - Digitalization In Management, Society And Economy, Podebrady, Sep. 6-8, pp. 55-60.

Wegmann, J., Jiao, J. (2017). Taming Airbnb: Toward guiding principles for local regulation of urban vacation rentals based on empirical results from five US cities. Land Use Policy, 69, 494-501.

Xie, K. L., \& Kwok, L. (2017). The effects of Airbnb's price positioning on hotel performance. International Journal of Hospitality Management, 67, 174-184.

Yrigoy, I. (2017). Airbnb in Menorca: a new form of touristic gentrification? Distribution of touristic housing dwelling, agents and impacts on the residential rent. Scripta Nova Revista Electrónica de Geografía y Ciencias Sociales, 21(580).

Yu, Z. J., Bai, H. F. (2017). Research on Tax Issues of Shared Economic Business Model. In: Proceedings Of The 2017 International Conference On Education, Economics And Management Research (ICEEMR 2017). 275-278

Zervas, G., Proserpio, D., \& Byers, J. W. (2017). The rise of the sharing economy: Estimating the impact of Airbnb on the hotel industry. Journal of Marketing Research, 54(5), 687-705. 